\title{
DETEKSI KEMIRIPAN SOURCE CODE DENGAN METODE FINGERPRINT BASED DISTANCE DAN LEVENSHTEIN DISTANCE
}

\author{
Jimmy $^{1}$, Viny Christanti M. ${ }^{2}$, Agus Budi D. ${ }^{3}$ \\ Program Studi Teknik Informatika, Fakultas Teknologi Informasi, Universitas Tarumanagara, \\ Jln. Letjen S. Parman No. 1, Jakarta, 11440, Indonesia \\ E-mail: ${ }^{3}$ jimmymsz@ymail.com, ${ }^{2}$ viny@untar.ac.id, ${ }^{3}$ agusd@fti.untar.ac.id
}

\begin{abstract}
Abstrak
Kemudahan mengakses informasi membuat semakin mudahnya melakukan plagiarisme. Plagiarisme tidak hanya terjadi pada makalah atau tulisan ilmiah, tetapi juga pada program komputer. Dalam paper ini akan dijelaskan metode untuk mendeteksi kemiripan setiap pasang source code secara otomatis. Metode yang digunakan adalah fingerprint based distance dan Levenshtein Distance. Hasil diukur dengan akurasi, precision, dan recall. Hasilnya, pada kumpulan data tertentu, Levenshtein Distance lebih baik daripada fingerprint based distance.
\end{abstract}

Kata kunci-Deteksi Kemiripan Source Code, Fingerprint Based Distance, Levenshtein Distance

\begin{abstract}
The ease of accessing information makes easier to do plagiarism. Plagiarism not only applied to written essay, but these day copying other people's program is also considered as plagiarism. This paper will researching an method to automatically calculating the similarity of pair of source code. The method used are fingerprint based distance and Levenshtein Distance. The result will be measured in accuracy, precision, and recall. The result is in some dataset, levenshtein distance is better than fingerprint based distance for detecting plagiarism in student's code especially beginner in $\mathrm{C}++$.
\end{abstract}

Keywords-Fingerprint Based Distance, Levenshtein Distance, Source Code Similarity Detection

\section{PENDAHULUAN}

Kemudahan mencari informasi melalui internet menyebabkan masalah dalam masyarakat, salah satunya plagiarisme.Ini menjadi masalah serius khususnya dalam bidang akademis.Plagiarisme tidak hanya terjadi dalam bentuk makalah atau karya tulis, tetapi juga dalam bentuk source code dari suatu program komputer. Deteksi kemiripan source code secara manual akan sangat memakan waktu jika jumlahnya banyak, karena itu dibutuhkan suatu metode yang tepat untuk mendeteksi kemiripan dari beberapa berkas source code secara otomatis.Metode untuk mendeteksi kemiripansource code berbeda dengan pendeteksian plagiarisme teks biasa.

Ada beberapa penelitian yang relevan. Metode sederhana untuk mengenali kemiripan dalam bahasa alami digunakan untuk source code. Teknik ini sangat sederhana, yaitu dengan mencocokkan huruf dan kata yang digunakan, dan bukan secara semantik [1]. Keuntungannya adalah mendeteksi kemiripan antar teks lebih cepat dan mudah diimplementasikan [2]. 
A Machine Learning Based Tool for Source Code Plagiarism Detection" yang dilakukan oleh Upul Bandara, dan Gamini Wijayarathna. Penelitian ini menggunakan algoritma klasifikasi Multinomial Naive Bayes, Bernoulli Naïve Bayes, dan k-Nearest Neighbor, lalu dikombinasikan ke Adaboost Meta-learning dengan tujuan memperkuat metode yang kurang baik. Penelitian yang dilakukan mengarah ke identifikasi penulis source code sebenarnya. Hasil dari penelitian menunjukkan akurasi 86.6 persen untuk dataset berjumlah 741 berkas [3].

Metode lainya dibuat oleh Gilad Mishne dan Maarteen de Rijke dari University of Amsterdam. Penelitiannya adalah membuat source code retrieval dengan menggunakan conceptual graph. Hasilnya tergolong baik, tetapi mempunyai kelemahan dalam kompleksitas. Proses yang dilakukan sangat banyak, jadi akan membutuhkan waktu proses yang sangat lama [4].

Pada penelitian ini, akan digunakan metode fingerprint based distancedan Levenshtein Distance. Metode fingerprint based distancediperkenalkan oleh Sandhya Narayanan dan Simi dalam penelitiannya yang berjudul Source Code Plagiarism Detection and Performance Analysis Using Fingerprint Based Distance Measure Method di tahun 2012. Penelitian yang dilakukan Sandhya Narayanan menyimpulkan bahwa metode fingerprint based distance mempunyai akurasi lebih dari $97 \%$ dan nilai presisi lebih dari 77\%[4].

Penelitian ini bertujuan untuk mengetahui pengaruh fitur dari source code dalam mendeteksi kemiripan source code dan membandingkan performa dari fingerprint based distance dan Levenshtein Distance. Pada penelitian akan digunakan beberapa skenario nilai bobot (weight) pada setiap fiturfingerprint based distance. Data yang akan digunakan adalah source code $\mathrm{C}++$ yang diperoleh dari pekerjaan mahasiswa kelas pemrograman $\mathrm{C}++$ lanjut Universitas Tarumanagara semester genap 2016/2017 yang kode soalnya adalah "Bayar atau Kabur".

\section{METODE PENELITIAN}

\subsection{Pengumpulan Data}

Data yang dikumpulkan berupa source code $\mathrm{C}++$. Dengan menggunakan data yang sudah dikumpulkan, diambil 15 yang dipercaya penulis sebagai tidak plagiat. Berdasarkan data tersebut, dibuatlah 35 file yang memplagiati file aslinya dengan berbagai macam jenis plagiat. Setiap pasang source code kemudian diberikan label "Plagiat" dan "Tidak Plagiat". Jumlah pasangan source code adalah 1225, yaitu setiap kombinasi 2 file dari 50 file yang tersedia. Jumlah pasangan yang dianggap plagiat berjumlah 61, dan sisanya 1164 diberikan label "Tidak Plagiat".

\subsection{Fingerprint Based Distance}

Fingerprint based distance dapat menentukan nilai similarity antar source code.Fitur yang digunakan dalam algoritma ini berdasarkan pada penelitian Halstead, mengenai properti yang dapat digunakan untuk membedakan suatu kode program dengan kode program lainnya. Untuk menghitung nilai similarity, diperlukan nilai dari setiap fitur terlebih dahulu. Anggap nilai fitur program $\mathrm{A}$ adalah $\mathrm{f}(\mathrm{A})$ dan nilai fitur program $\mathrm{B}$ adalah $\mathrm{f}(\mathrm{B})$. Sehingga rasio $\delta$ dapat dihitung dengan rumus berikut[4]. 


$$
\delta_{i}=\left\{\begin{array}{l}
\frac{f_{i}(A)}{f_{i}(B)} \text { jika } f_{i}(B)>f_{i}(A) \\
\frac{f_{i}(B)}{f_{i}(A)} \text { jika } f_{i}(A) \geq f_{i}(B)
\end{array}\right.
$$

$\delta$ adalah rasio dari fitur antara program A dan program B, yang sudah dihitung di tahap atas. $\mathrm{W}_{\mathrm{i}}$ adalah nilai bobot dari fitur.Similarity score atau angka kemiripan (direpresentasikan dengan $\Delta$ ) dapat dihitung dengan rumus berikut[4].

$$
\Delta=\frac{\sum_{i=1}^{n} w_{i} * \delta_{i}}{n}
$$

\subsection{Levenshtein Distance}

Levenshtein Distance merupakan salah satu metode yang cukup populer untuk mencari jarak terpendekantara dua string. Metode ini dibuat oleh Vladimir Levensthein tahun 1965. Metode ini juga dikenal sebagai edit distance (ED). Jika diketahui terdapat string s1 dan s2, maka jaraknya adalah operasi penyuntingan minimal yang dibutuhkan untuk mengubah s1 menjadi s2. Operasi yang dimaksud adalah menyisipkan satu karakter, menghapus satu karakter, dan mengganti (substitusi) satu karakter menjadi karakter lain[5]. Secara matematis, Levenshtein Distance antara dua string, a dan $\mathbf{b}$, adalah sebagai berikut.

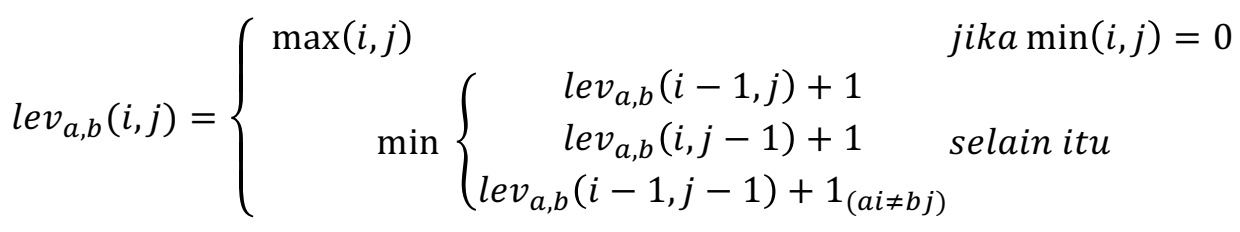
berikut.

Pengubahan dari nilai distance menjadi similarity dapat dihitung dengan rumus sebagai

$$
\operatorname{sim}_{a, b}=\frac{\max (|A|,|B|)-\operatorname{lev}_{a, b}}{\max (|A|,|B|)}
$$

$\operatorname{Sim}_{\mathrm{a}, \mathrm{b}}$ adalah nilai kemiripan antara a dan $\mathrm{b}$. $|\mathrm{A}|$ adalah panjang dari string A. Leva,b adalah hasil perhitungan Levenshtein Distance sebelumnya.

\subsection{Evaluasi}

Evaluasi merupakan langkah terakhir yang diperlukan untuk menyatakan bahwa sistem yang dibuat sudah berjalan sesuai dengan yang diharapkan. Evaluasi penelitian ini akan menggunakan nilai akurasi, precision dan recall. Masing-masing dari pasangan tersebut diketahui keadaan sebenarnya apakah orisinil atau hasil jiplakan. Setiap dari hasil uji akan diberi label, yang akan dicocokkan pada keadaan sebenarnya.

Apabila hasil deteksi menyatakan P (plagiat), dan sebenarnya adalah P (plagiat), maka dapat diberi label TP (True Positive). Apabila hasil deteksi menyatakan P (plagiat), dan sebenarnya adalah NP (non-plagiat), maka dapat diberi label FP (False Positive). Apabila hasil deteksi menyatakan NP (non-plagiat), dan keadaan sebenarnya adalah P (plagiat), maka dapat diberi label FP (False Negative). Apabila hasil deteksi menyatakan NP (non-plagiat), dan sebenarnya adalah (non-plagiat), maka dapat diberi label TN (True Negative). 
Precision dan recall adalah teknik untuk mengukur keefektifan suatu algoritma, terutama di bidang pengenalan pola dan information retrieval. Dalam penelitian ini, precision adalah nilai perbandingan antara jumlah berkas yang plagiat dan dideteksi sebagai plagiat dengan jumlah berkas yang terdeteksi sebagai plagiat, sedangkan recall adalah nilai perbandingan antara jumlah berkas yang plagiat dan terdeteksi sebagai plagiat dengan jumlah dokumen yang sebenarnya plagiat. Rumusan untuk menghitung nilai precision, recall, dan akurasi adalah sebagai berikut.

$$
\begin{gathered}
\text { precision }=\frac{\mathrm{TP}}{\mathrm{TP}+\mathrm{FP}} \\
\text { recall }=\frac{\mathrm{TP}}{\mathrm{TP}+\mathrm{FN}} \\
\text { akurasi }=\frac{\mathrm{TP}+\mathrm{TN}}{\mathrm{TP}+\mathrm{TN}+\mathrm{FP}+\mathrm{FN}}
\end{gathered}
$$

Setiap paragraf diawali dengan $1 \mathrm{~cm}$ ke dalam (first line). Sub bab diberi nomor dan rata kiri. Organisasi naskah meliputi pendahuluan, metode, eksperimen/hasil dan pembahasan, kesimpulan, dan referensi. Lampiran (jika ada) ditulis setelah kesimpulan dan sebelum referensi dan tidak bernomor. Jarak antara paragraf adalah satu spasi.

\section{HASIL DAN PEMBAHASAN}

Pengujian pada program yang sudah dirancang dibagi menjadi 2 (dua) bagian, yaitu pengujian metode Leveshstein distance, serta pengujian metode fingerprint based distance dengan bobot yang sudah ditentukan pada Tabel 4 .

\subsection{Pengujian Levenshtein Distance}

Pengujian yang dilakukan bertujuan untuk menghasilkan tingkat keakuratan metode Levenshtein Distance dalam menentukan plagiarisme source code. Hasil dari perhitungan berupa angka kemiripan. Hasil ini akan diberi label, jika melewati threshold, maka akan diberi label "Plagiat". Setiap hasil dari metode Levenshtein Distance akan dicocokkan ke kelas sebenarnya, dan akan dihitung jumlah True Positive, True Negative, False Positive, dan False Negative. Setelah itu, dihitunglah nilai precision, recall, dan akurasi dari setiap kasus uji. Hasil Pengujian dapat dilihat pada Tabel 1dan Gambar 1.

Tabel 1 Hasil Pengujian Levenshtein Distance dengan Threshold Tertentu

\begin{tabular}{|c|c|c|c|c|c|c|c|}
\hline \multirow{2}{*}{ Keterangan } & \multicolumn{7}{|c|}{ Threshold } \\
\cline { 2 - 8 } & $\mathbf{5 0 \%}$ & $\mathbf{5 5 \%}$ & $\mathbf{6 0 \%}$ & $\mathbf{6 5 \%}$ & $\mathbf{7 0 \%}$ & $\mathbf{7 5 \%}$ & $\mathbf{8 0 \%}$ \\
\hline TP & 60 & 60 & 60 & 59 & 58 & 55 & 47 \\
\hline TN & 1108 & 1156 & 1159 & 1163 & 1163 & 1163 & 1163 \\
\hline FP & 56 & 8 & 5 & 1 & 1 & 1 & 14 \\
\hline FN & 1 & 1 & 1 & 2 & 3 & 6 & 1 \\
\hline Precision & $51.72 \%$ & $88.24 \%$ & $92.31 \%$ & $98.33 \%$ & $98.31 \%$ & $98.21 \%$ & $97.92 \%$ \\
\hline Recall & $98.36 \%$ & $98.36 \%$ & $98.36 \%$ & $96.72 \%$ & $95.08 \%$ & $90.16 \%$ & $77.05 \%$ \\
\hline Accuracy & $95.35 \%$ & $99.27 \%$ & $99.51 \%$ & $99.76 \%$ & $99.67 \%$ & $99.43 \%$ & $98.78 \%$ \\
\hline
\end{tabular}




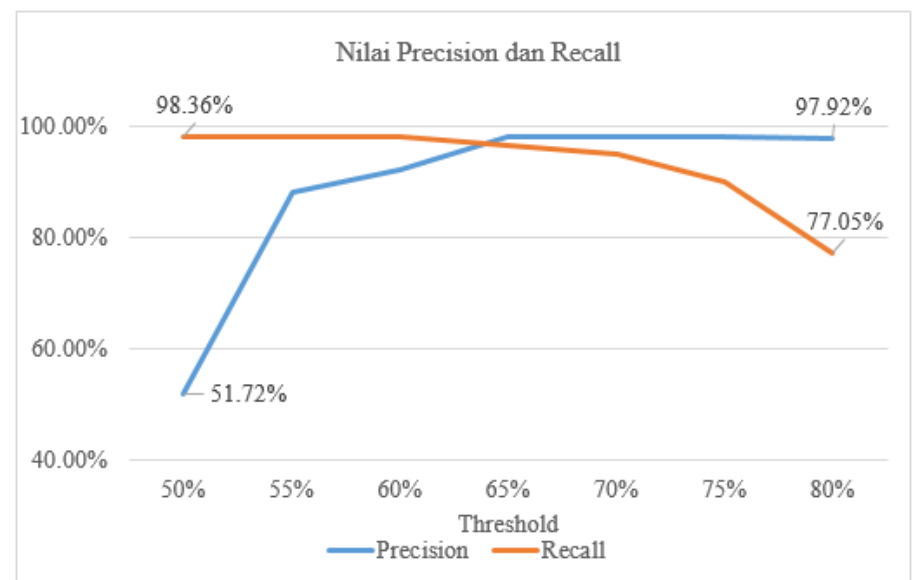

Gambar 1 Hasil Pengujian Levenshtein Distance

Hal lain yang dilakukan pada pengujian ini adalah pengukuran performa dari Levenshtein Distance. Hal yang dijadikan variabel bebas adalah jumlah source code yang digunakan. Variabel kontrolnya adalah setiap source code dibuat sama yaitu kurang lebih 2000 karakter sebelum dihapus komentar dan spasinya oleh sistem. Varibel terikatnya adalah waktu eksekusi yang dibutuhkan sistem. Hasil dapat dilihat pada Tabel 2 dan Gambar 2.

Tabel 2 Perbandingan Waktu Eksekusi Levenshtein

\begin{tabular}{|c|c|c|}
\hline $\begin{array}{c}\text { Jumlah file } \\
\text { source code }\end{array}$ & Jumlah Perbandingan & Waktu (ms) \\
\hline 5 & 10 & 292 \\
\hline 10 & 45 & 1400 \\
\hline 15 & 105 & 3117 \\
\hline 20 & 190 & 5460 \\
\hline 25 & 300 & 8482 \\
\hline 30 & 435 & 12286 \\
\hline 35 & 595 & 17533 \\
\hline 40 & 780 & 21878 \\
\hline 45 & 990 & 28434 \\
\hline 50 & 1225 & 34610 \\
\hline
\end{tabular}

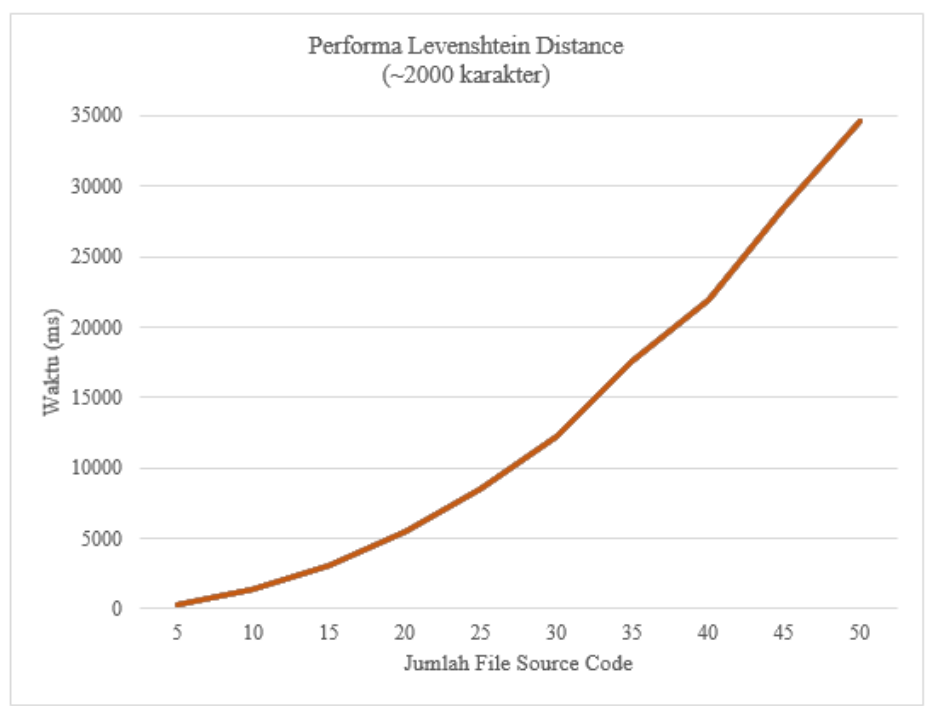

Gambar 2 Perbandingan Waktu Eksekusi Levenshtein 


\subsection{Pengujian Fingerprint Based Distance}

Pengujian kedua ini menggunakan data uji yang sama dengan pengujian pertama. Pengujian ini bertujuan menentukan nilai bobot (weight) dari fingerprint based distance yang cocok dalam menentukan plagiarisme source code. Setiap hasil yang dihasilkan metode ini akan dicocokkan ke kelas sebenarnya yang sudah ditentukan. Terdapat 13 macam skenario uji yang akan dilakukan. Nilai bobot setiap fitur yang dijadikan skenario uji dapat dilihat pada Tabel 4. Nilai threshold yang digunakan akan menggunakan nilai threshold yang cukup optimal dari percobaan sebelumnya, yaitu $65 \%$. Tabel 3 menunjukkan ciri dari source code yang dijadikan fitur dari fingerprint based distance.Tabel 4 menunjukkan bobot dari setiap fitur di setiap percobaan.

Tabel 3 Fitur dari Fingerprint Based Distance

\begin{tabular}{|c|c|}
\hline No & Fitur \\
\hline 1 & jumlah input \\
\hline 2 & jumlah output \\
\hline 3 & operator yang muncul \\
\hline 4 & operand yang muncul \\
\hline 5 & operator yang unik \\
\hline 6 & operand yang unik \\
\hline 7 & volume \\
\hline 8 & jumlah baris \\
\hline 9 & komentar \\
\hline
\end{tabular}

Tabel 4 Bobot Fitur Setiap Percobaan

\begin{tabular}{|c|c|c|c|c|c|c|c|c|c|}
\hline \multirow{2}{*}{ Percobaan } & \multicolumn{7}{|c|}{ Bobot fitur } \\
\cline { 2 - 11 } & F1 & F2 & F3 & F4 & F5 & F6 & F7 & F8 & F9 \\
\hline Percobaan 1 & - & - & - & - & - & - & 1 & 1 & - \\
\hline Percobaan 2 & - & - & 1 & 1 & 1 & 1 & - & - & - \\
\hline Percobaan 3 & 1 & 1 & - & - & - & - & - & - & - \\
\hline Percobaan 4 & 1 & 1 & - & - & - & - & 1 & 1 & - \\
\hline Percobaan 5 & 1 & 1 & 1 & 1 & 1 & 1 & - & - & - \\
\hline Percobaan 6 & - & - & 1 & 1 & 1 & 1 & 1 & 1 & - \\
\hline Percobaan 7 & 1 & 1 & 1 & 1 & 1 & 1 & 1 & 1 & - \\
\hline Percobaan 8 & 1 & 1 & 0.8 & 1 & 0.8 & 1 & 1 & 1 & - \\
\hline Percobaan 9 & 1 & 1 & 1 & 0.8 & 1 & 0.8 & 1 & 1 & - \\
\hline Percobaan 10 & 1 & 1 & 0.6 & 0.6 & 0.6 & 0.6 & 0.5 & 1 & - \\
\hline Percobaan 11 & 1 & 1 & 1 & 1 & 1 & 1 & 1 & 1 & 0.6 \\
\hline Percobaan 12 & 1 & 1 & 1 & 1 & 1 & 1 & 1 & - & - \\
\hline Percobaan 13 & 1 & 0.1 & 1 & 0.9 & 0.7 & 1 & 0.1 & 1 & - \\
\hline
\end{tabular}

Bobot dari setiap fitur dapat diatur bebas dalam rentang 0 sampai 1. Jika bobot fiturnya 0 , maka dapat dianggap fitur tersebut diabaikan dan tidak perlu dihitung. Dengan mengggunakan bobot fitur pada tabel di atas, diperoleh hasil pengujian. Hasil pengujian dapat dilihat pada Tabel 5. 
Computatio: Journal of Computer Science and Information Systems, Volume 2, No 1, April 2018

Tabel 5 Hasil Pengujian Fingerprint Based Distance (Bagian I)

\begin{tabular}{|c|c|c|c|c|c|c|c|}
\hline \multirow{2}{*}{ Keterangan } & \multicolumn{7}{|c|}{ Skenario } \\
\cline { 2 - 8 } & $\mathbf{1}$ & $\mathbf{2}$ & $\mathbf{3}$ & $\mathbf{4}$ & $\mathbf{5}$ & $\mathbf{6}$ & $\mathbf{7}$ \\
\hline TP & 60 & 57 & 60 & 60 & 57 & 57 & 57 \\
\hline TN & 322 & 599 & 503 & 358 & 605 & 500 & 541 \\
\hline FP & 842 & 565 & 661 & 806 & 559 & 664 & 623 \\
\hline FN & 1 & 4 & 1 & 1 & 4 & 4 & 4 \\
\hline Precision & $6.65 \%$ & $9.16 \%$ & $8.32 \%$ & $6.93 \%$ & $9.25 \%$ & $7.91 \%$ & $8.38 \%$ \\
\hline Recall & $98.36 \%$ & $93.44 \%$ & $98.36 \%$ & $98.36 \%$ & $93.44 \%$ & $93.44 \%$ & $93.44 \%$ \\
\hline Accuracy & $31.18 \%$ & $53.55 \%$ & $45.96 \%$ & $34.12 \%$ & $54.04 \%$ & $45.47 \%$ & $48.82 \%$ \\
\hline
\end{tabular}

Tabel 6 Hasil Pengujian Fingerprint Based Distance (Bagian II)

\begin{tabular}{|c|c|c|c|c|c|c|}
\hline \multirow{2}{*}{ Keterangan } & \multicolumn{7}{|c|}{ Skenario } \\
\cline { 2 - 7 } & $\mathbf{8}$ & $\mathbf{9}$ & $\mathbf{1 0}$ & $\mathbf{1 1}$ & $\mathbf{1 2}$ & $\mathbf{1 3}$ \\
\hline TP & 57 & 57 & 57 & 57 & 57 & 55 \\
\hline TN & 614 & 614 & 1054 & 716 & 553 & 1073 \\
\hline FP & 550 & 550 & 110 & 448 & 611 & 91 \\
\hline FN & 4 & 4 & 4 & 4 & 4 & 6 \\
\hline Precision & $9.39 \%$ & $9.39 \%$ & $34.13 \%$ & $11.29 \%$ & $8.53 \%$ & $37.67 \%$ \\
\hline Recall & $93.44 \%$ & $93.44 \%$ & $93.44 \%$ & $93.44 \%$ & $93.44 \%$ & $90.16 \%$ \\
\hline Accuracy & $54.78 \%$ & $54.78 \%$ & $90.69 \%$ & $63.10 \%$ & $49.80 \%$ & $92.08 \%$ \\
\hline
\end{tabular}

Hasil terbaik ada pada skenario-13. Hal ini terlihat pada akurasinya yaitu $92.08 \%$ dengan precision sebesar $37.67 \%$ dan recall sebesar $90.16 \%$. Hasil dengan akurasi terkecil ada pada skenario-1, yaitu nilai akurasi $31.18 \%$ dengan precision $6.65 \%$ dan recall $98.36 \%$.

Sama seperti metode Levenshtein Distance, dilakukan pengukuran performa dari fingerprint based distance dengan melihat waktu eksekusi yang diperlukan. Variabel kontrol dibuat sama yaitu jumlah karakter dalam setiap source code yaitu kurang lebih 2000 karakter sebelum dihapus komentar dan spasi oleh sistem. Hasil pengujian dapat dilihat pada Gambar 3 .

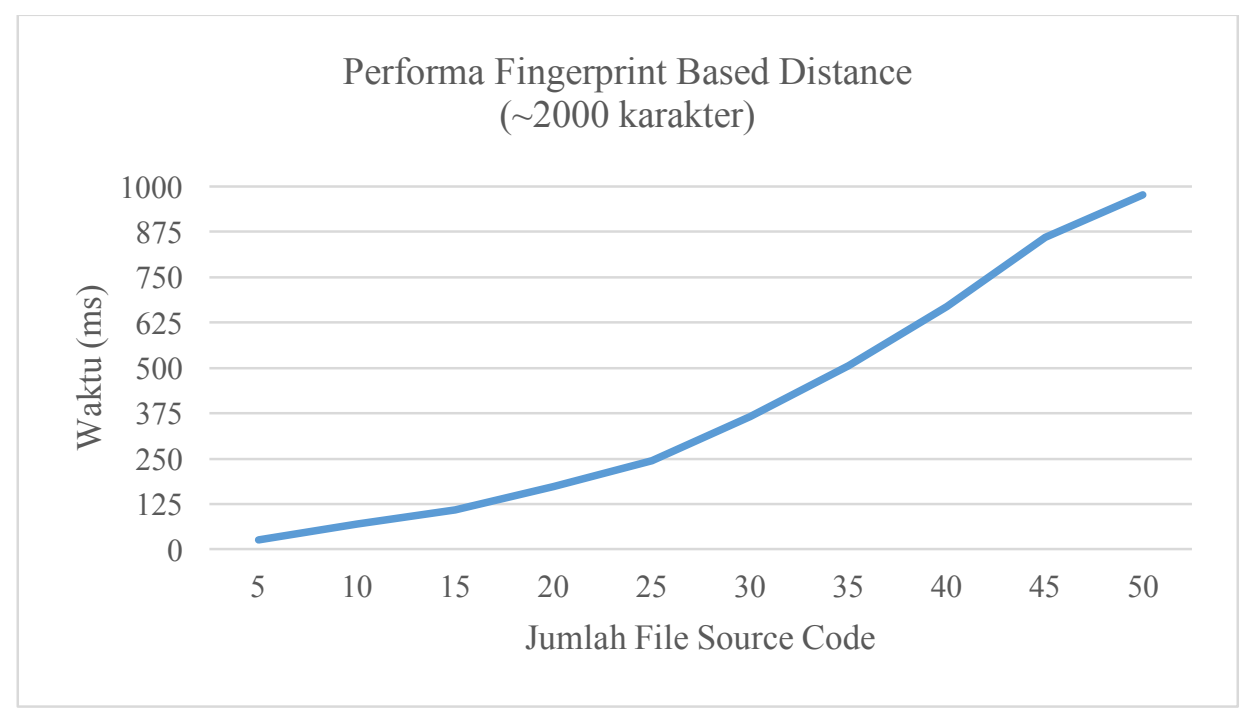

Gambar 3 Perbandingan Waktu Eksekusi Fingerprint Based Distance 
Waktu yang diperlukan fingerprint based distance relatif cepat jika dibandingkan dengan Levenshtein Distance, bahkan 1225 perbandingan dapat selesai kurang dari 1 detik. Lebih lengkapnya dapat dilihat pada Tabel 6.

Tabel 6Perbandingan Waktu Eksekusi Fingerprint Based Distance

\begin{tabular}{|c|c|c|}
\hline $\begin{array}{c}\text { Jumlah file } \\
\text { source code }\end{array}$ & Jumlah Perbandingan & Waktu (ms) \\
\hline 5 & 10 & 26 \\
\hline 10 & 45 & 70 \\
\hline 15 & 105 & 109 \\
\hline 20 & 190 & 173 \\
\hline 25 & 300 & 245 \\
\hline 30 & 435 & 366 \\
\hline 35 & 595 & 507 \\
\hline 40 & 780 & 669 \\
\hline 45 & 990 & 859 \\
\hline 50 & 1225 & 976 \\
\hline
\end{tabular}

Waktu yang diperlukan relatif stabil, sehingga memungkinkan untuk memproses source code dengan jumlah yang lebih banyak.

\subsection{Pembahasan}

Pembahasan yang akan dijelaskan adalah mengenai Levenshtein Distance dan fingerprint based distance dalam mendeteksi plagiarisme source code sesuai hasil pengujian yang telah dilakukan.

\subsubsection{Pembahasan Levenshtein Distance}

Dari hasil pengujian pada subbab sebelumnya, dapat terlihat bahwa Levenshtein Distance mampu untuk mendeteksi plagiarisme source code, dan mempunyai nilai precision dan recall yang cukup tinggi. Nilai precision tertinggi terdapat pada threshold $65 \%$ yaitu $98.33 \%$. Sedangkan nilai recall tertinggi yaitu $98.36 \%$.

Terdapat sedikit prediksi salah pada metode Levenshtein Distance. Di antaranya, Levenshtein Distance tidak mampu untuk mendeteksi apabila terjadi banyak perubahan pada struktur source code. Selain itu, perubahan ekspresi aljabar yang banyak juga akan sulit dideteksi oleh metode ini.

Salah satu kelebihan metode ini yang terlihat dari hasil pengujian adalah sedikitnya false negative yang dihasilkan. Ini berarti dari data yang digunakan, pasangan yang sebenarnya plagiat akan lebih sering dideteksi sebagai plagiat, dibandingkan sebagai non-plagiat.

Kelemahan dari metode ini yang terlihat dari hasil pengujian yang telah dilakukan adalah lebih sulit dalam mendeteksi perubahan nama variabel. Selain itu, perubahan urutan eksekusi program, misalnya inisialisasi variabel yang diacak-acak juga akan menurunkan nilai kemiripan. Perubahan ekspresi aljabar seperti menambahkan tanda kurung, atau mengubah alur perhitungan aritmatika juga akan menurunkan nilai kemiripan antar source code.

Terdapat beberapa alasan mengapa nilai precision dan recall yang didapat pada pengujian ini tinggi. Pertama, solusi dari soal yang digunakan cukup sederhana. Kedua, solusi dari soal 
yang didapat terlalu pendek. Ketiga adalah pengetahuan mahasiswa yang mengerjakan hampir sama, sehingga menggunakan cara pengerjaan yang sederhana.

\subsubsection{Pembahasan Fingerprint Based Distance}

Dari hasil pengujian, dapat terlihat bahwa hasil dari fingerprint based distance mempunyai nilai precision dan recall yang relatif rendah jika dibandingkan dengan metode Levenshtein Distance. Nilai precision tertinggi terdapat pada skenario-10 yaitu $34.13 \%$. Sedangkan nilai recall yang dihasilkan pada skenario yang sama termasuk tinggi, yaitu $93.44 \%$.

Terdapat relatif banyak prediksi salah pada metode fingerprint based distance. Jika dilihat dari skenario-10, jumlah true positive adalah 57, sedangkan false positive berjumlah 110. Ini berarti terdapat banyak pasangan yang sebenarnya tidak plagiat namun teridentifikasi metode ini sebagai plagiat.

Secara teoritis, kelebihan metode ini adalah dapat mendeteksi jika terdapat perubahan nama variabel, maupun perubahan eksekusi kode. Kecilnya nilai precision dapat berarti terdapat banyak kesalahan pendeteksian dimana pasangan source code yang seharusnya tidak plagiat, dideteksi sebagai plagiat. Hal ini dapat disebabkan oleh pengetahuan mahasiswa yang mengerjakan hampir sama, sehingga menggunakan cara pengerjaan yang hampir sama pula. Karena source code ini diperoleh dari mahasiswa semester 2 (dua), maka pengetahuan mahasiswa masih terlalu sedikit untuk menjawab pertanyaan dengan cara yang tidak umum. Solusi dari soal "Bayar atau Kabur" yang dipilih sebagai data uji juga terlalu pendek pada umumnya.

Beberapa hal yang dapat dilakukan untuk memiminalisasi nilai kesalahan prediksi adalah dengan menggunakan nilai bobot yang kecil pada setiap fiturnya. Hal ini terlihat pada hasil pengujian, nilai bobot yang rendah lebih akurat untuk pengetahuan mahasiswa yang sederhana. Pada pengujian di atas menggunakan nilai threshold $65 \%$. Mengatur nilai threshold dengan nilai yang lebih tinggi disarankan untuk meminimalisasi kesalahan prediksi.

\subsubsection{Pembahasan Keseluruhan}

Levenshtein Distance mempunyai akurasi yang lebih baik dikarenakan struktur program pada setiap mahasiswa yang tidak saling plagiat secara kasat mata tidak sama. Hal ini sangat mirip dengan cara pendeteksian plagiarisme secara manual, tetapi lebih cepat.

Fingerprint based distance dilihat dari hasil pengujian kurang baik jika diatur nilai threshold $65 \%$. Penyebab utamanya adalah secara tersirat, maksud dari program adalah sama, sehingga metode ini salah prediksi dan menyebabkan pasangan source code yang tidak plagiat terdeteksi sebagai plagiat. Bobot dari setiap fitur juga sangat berpengaruh terhadap nilai precision dan recall yang dihasilkan.

Pendeteksian plagiarisme di antara 2 metode yang sudah diuji, maka dapat dikatakan Levenshtein Distance lebih akurat dibandingkan dengan fingerprint based distance. Fingerprint based distance dapat mendeteksi makna dalam program lebih baik, tetapi untuk pendeteksian tugas mahasiswa yang sederhana kurang cocok.

Dalam hal waktu yang diperlukan, metode Levenshtein Distance dapat dikatakan cukup lambat jika dibandingkan dengan metode fingerprint based distance. Hal ini disebabkan karena dalam metode Levenshtein Distance, perlu membuat matriks berukuran panjang source code A dikali panjang source code B, lalu akan diisi setiap selnya. Hal ini sangat berbeda dengan 
metode fingerprint based distance yang secara langsung mencari token-token penting yang dibutuhkan.

Dengan demikian, untuk dapat mendeteksi plagiarisme source code dengan baik, sistem yang dibutuhkan adalah sistem yang dapat menghitung kemiripan semua pasang source code yang diunggah dengan menggunakan kedua metode yang tersedia sehingga dapat menunjang keputusan apakah source code yang ditulis adalah plagiat atau bukan dengan baik.

\subsection{Pengujian dengan Data yang Berbeda}

Selain menggunakan data yang sudah disebutkan, pengujian juga dilakukan untuk data yang berbeda. Ada 2 sumber data yang lain yaitu pekerjaan mahasiswa dengan kode soal "perkalian-kuda" (selanjutnya disebut Kumpulan Data-2) dan hasil pekerjaan pengguna Hackerrank dengan kode soal "Hackerland Radio Transmitters" (selanjutnya disebut Kumpulan Data-3).

Hasilnya, untuk kumpulan data-2, Levenshtein Distance menghasilkan akurasi 98.94\%, dengan precision $93.75 \%$ dan recall $100.00 \%$. Untuk fingerprint based distance, skenario dengan hasil terbaik ada pada percobaan 13 , dengan akurasi $99.47 \%$, precision $96.77 \%$ dan recall $100.00 \%$.

Hasilnya, untuk kumpulan data-3, Levenshtein Distance menghasilkan akurasi 99.47\%, dengan precision $95.24 \%$ dan recall $100.00 \%$. Untuk fingerprint based distance, skenario dengan hasil terbaik ada pada percobaan 13 , dengan akurasi $88.95 \%$, precision $48.78 \%$ dan recall $100.00 \%$.

\section{KESIMPULAN}

Kesimpulan yang didapat dari semua pengujian yang telah dilakukan dalam penelitian ini adalah sebagai berikut.

1. Fitur yang paling berpengaruh dalam menentukan kemiripan source code adalah jumlah input, operator yang muncul, operand unik, dan jumlah baris.

2. Pada penelitian ini, metode Levenshtein Distance dengan nilai threshold $65 \%$ mencapai akurasi tertinggi sebesar $99.76 \%$ dengan nilai precision sebesar $98.33 \%$ dan recall sebesar $96.72 \%$.

3. Pada penelitian ini, metode fingerprint based distance dengan nilai threshold $65 \%$ menghasilkan nilai akurasi tertinggi pada skenario-13 yaitu $92.08 \%$ dengan nilai precision sebesar $37.67 \%$ dan recall sebesar $90.16 \%$.

Beberapa saran yang diberikan untuk pengembangan penelitian selanjutnya adalah sebagai berikut.

1. Dapat dilakukan pencarian nilai optimal untuk setiap nilai fitur yang belum dilakukan dalam penelitian ini.

2. Dapat dilakukan perbandingan nilai kemiripan dari suatu source code yang disalin ke bahasa pemrograman lain. 


\section{DAFTAR PUSTAKA}

[1] J.I. Maletic and Marcus, 2000, Using latent semantic analysis to identify similarities in source code to support program understanding, Proceedings of the 12th International Conference on 2000

[2] Marcus and J.I. Maletic, 2001, Identification of high-level concept clones in source code, Proceedings of the 16th International Conference on Automated Software Engineering (ASE 2001)

[3] Bandara, Upul and Gamini Wijayarathna, 2011, A Machine Learning Based Tool for Source Code Plagiarism Detection, International Journal of Machine Learning and Computing, Vol.I, hal. 337

[4] Narayanan, Sandhya and Simi S., 2012, Source Code Plagiarism Detection and Performance Analysis Using Fingerprint Based Distance Measure Method, International Conference on Computer Science \& Education, Vol. VII, hal.1066

[5] Manning, Christopher D., 2009, An Introduction to Information Retrieval, Cambridge University Press, Cambridge. 